\title{
The Role of Oxygen in the Copper-Catalyzed Decomposition of Phenylborates in Aqueous Alkaline Solutions
}

by

\author{
M. L. Hyder
}

Westinghouse Savannah River Company

Savannah River Site

Aiken, South Carolina 29808

DOE Contract No. DE-AC09-96SR18500

This paper was prepared in connection with work done under the above contract number with the U. S. Department of Energy. By acceptance of this paper, the publisher and/or recipient acknowledges the U. S. Government's right to retain a nonexclusive, royalty-free license in and to any copyright covering this paper, along with the right to reproduce and to authorize others to reproduce all or part of the copyrighted paper. 


\section{DISCLAIMER}

This report was prepared as an account of work sponsored by an agency of the United States Government. Neither the United States Government nor any agency thereof, nor any of their employees, makes any warranty, express or implied, or assumes any legal liability or responsibility for the accuracy, completeness, or usefulness of any information, apparatus, product, or process disclosed, or represents that its use would not infringe privately owned rights. Reference herein to any specific commercial product, process, or service by trade name, trademark, manufacturer, or otherwise does not necessarily constitute or imply its endorsement, recommendation, or favoring by the United States Government or any agency thereof. The views and opinions of authors expressed herein do not necessarily state or reflect those of the United States Government or any agency thereof.

This report has been reproduced directly from the best available copy.

Available to DOE and DOE contractors from the Office of Scientific and Technical Information, P.O. Box 62, Oak Ridge, TN 37831; prices available from (615) 576-8401.

Available to the public from the National Technical Information Service, U.S. Department of Commerce, 5285 Port Royal Road, Springfield, VA 22161. 


\section{DISCLAIMER}

Portions of this document may be illegible electronic image products. Images are produced from the best available original document. 
WSRC-TR-97-0069

The Role of Oxygen in the Copper-Catalyzed Decomposition of Phenyl Borates in Aqueous Alkaline Solutions (U)

M. Lee Hyder .

Westinghouse Savannah River Company

Savannah River Site Alken, South Carolina 29808

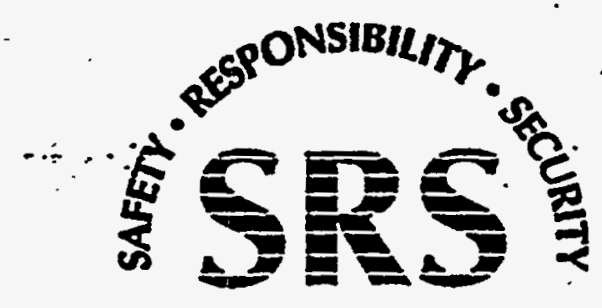


WSRC-TR-97-0069

March 17, 1997

The Role of Oxygen in the Copper-

Catalyzed Decomposition of Phenyl

Borates in Aqueous Alkaline Solutions

Oarrel Q. Ealleer 3/18/a7

D. D. Walker, (Waste Processing Technology) (Date)

(per Manual E7, Procedure 2.40)

Lenectere

$3-18-97$

S. D. Fink, Level 4 Manager, Waste Processing Technology

it) 2 Tapreteres

W. L. Tamosaitis, Level 3.Manager; Waste Processing Technology (Date)

$\frac{3 / 3 / / 5)}{\text { 15. T. Carter, In-Tank Precipitation Flow-Sheet Team Leader }}$

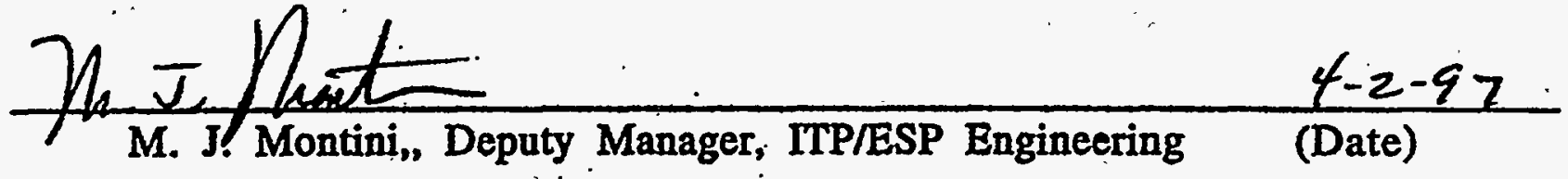

Westinghouse Savannah River Company

Savannah River Site

Aiken, SC 29808

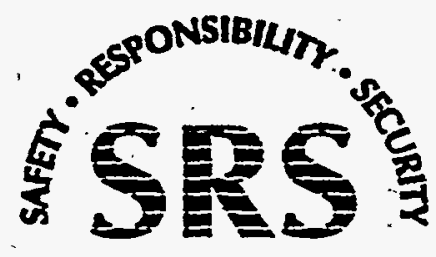


1. Oxygen Meter with Probe 15

2. Oxygen Probe $\quad 16$

3. Schematic Drawing of a Sample Cell 17

4. Measurement Cell (Pyrex Glass) : 18

5. Cu-Catalyzed Decomposition of TPB- 19

6. 1PB Aeration Experiment $\quad 20$

7. Continuously Aerated 1PB . . $\quad .21$

8. Mixed TPB- and 1PB Solution $\quad 22$

\section{List of Tables Page}

1. Copper-Catalyzed Hydrolysis of Sodium

Tetraphenylborate(TPB) Solution

2. Copper-Catalyzed Hydrolysis of Phenylboronic Acid (IPB)

3. Phenylboronic Acid (1PB). Destruction in Continuously. Aierated Solution

4. Reaction of Mixed PBA/NaTPB Solutions

5. Copper-Catalyzed Reactions of Triphenylborane

14

6. Copper-Catalyzed Reactions of Diphenylborinic Acid 


\title{
The Role of Oxygen in the Copper-Catalyzed Decomposition of Phenyl Borates in Aqueous Alkaline Solutions (U)
}

\author{
By M. Lee Hyder \\ Westinghouse Savannah River Company \\ Savannah River Site \\ Aiken, South Carolina 29808
}

\section{Abstract}

The effect of oxygen on the copper-catalyzed hydrolysis of phenyl borates containing from one to four phenyl groups was studied in $1 \mathrm{M}$ aqueous sodium hydroxide solution at $59^{\circ} \mathrm{C}$. Oxygen concentrations were followed using a YSI oxygen meter and electrochemical probe. Oxygen was found to have a significant effect on hydrolysis for each compound studied, although the nature of this effect varied greatly among the phenyl borates. The hydrolysis of the tetraphenylborate ion was not measurable in the presence of air, but became significant in anaerobic solutions. Triphenylboron hydrolyzes slowly in aerated solutions, but more rapidly in anaerobic solutions. In contrast, both diphenylborinic acid and phenylboronic acid hydrolyze very quickly in the presence of air, but much slower in anaerobic solutions. Phenylboronic acid hydrolysis in anaerobic solutions was too slow to be quantified.

The results are tentatively explained if the effective catalyst for each of the reactions is either cupric or cuprous ion, with the latter being present in significant concentration only in the absence of air. .

\section{Introduction}

The In-Tank Precipitation process recovers and concentrates radioisotopes from high-level waste solutions at the Savannah River Site (SRS). The principal soluble radioisotope in such solutions is ${ }^{187} \mathrm{Cs}$, which is isolated by precipitation with the tetraphenylborate (TPB-) ion. The resulting cesium tetraphenylborate is very insoluble, and can be separated from the bulk solution by filtration.

The tetraphenylborate ion is stable under normal conditions in neutral and alkaline solutions. In the SRS high level waste process, acid hydrolysis with copper catalysis $(\mathrm{Cu}=1 \mathrm{~g} / \mathrm{L})$ is used to remove the organic components from feed to the glass melter. The TPB-ion was expected to be quite stable in the alkaline radioactive waste solutions, in which the solubilities of multivalent metal ions are very small. It was therefore surprising when, during initial operation of the In-Tank Process during late 1995, dissolved TPB-was observed to decompose quantitatively over a period of a few months into benzene and other products. 1 Subsequent laboratory tests have confirmed 
that catalytic hydrolysis of 'TPB' can occur in alkaline aqueous solution, 2 although the solubilities of dissolved catalysts such as copper at high $\mathrm{pH}$ are in the range of milligrams or tens of milligrams per liter. ${ }^{3}$ Copper has been confirmed as a catalyst for the hydrolytic decomposition of dissolved TPB- in alkaline solutions, and there is evidence that other components in the waste may also have catalytic properties. 2 The laboratory studies also showed that hydrolysis is strongly dependent on temperature. Elevated temperatures (50 to $55^{\circ} \mathrm{C}$ ) were generated in the plant process by the mechanical heating from operation of circulating pumps. ${ }^{1}$

Initial laboratory investigations suggested a role for oxygen in the coppercatalyzed decomposition of TPB -.2 Phenol was observed as a hydrolysis product in the presence of oxygen, and there was also evidence that oxygen could affect the onset of hydrolysis. The studies reported here were undertaken in response to a Technical Task Request (TTR) 4 to gain definitive information on the involvement of oxygen in the TPBdecomposition. Task ${ }^{5}$ and $\mathrm{QA}^{6}$ plans were developed and followed throughout this work.

\section{Experimental}

Oxygen measurements reported here were made using a Model 58 oxygen meter and Model 5739 probe manufactured by YSI, Inc., of Yellow Springs, Ohio. (Figs. 1,2) The probe consists of a small electrochemical cell enclosed in a cylindrical plastic housing. The cell contains $\mathrm{KCl}$ solution as an electrolyte, and is separated from surrounding air or liquids by a fluorocarbon membrane (about $1 \mathrm{~cm}$ in diameter) that is permeable to oxygen but not to liquids. When a voltage is imposed on this cell, a current is generated proportional to the rate at which oxygen is reduced. Because the reduction of oxygen is fast compared to its diffusion through the semi-permeable membrane, this current is proportional to the flow of oxygen through the membrane. The rate of oxygen flow across the membrane, from the surrounding medium containing oxygen into the cell, is determined by the oxygen activity in the external medium. This activity is the same in air as in air-saturated fluids, so the cell is readily calibrated using ambient air as the standard.

The YSI instrument was made for use in measuring oxygen concentrations in natural waters, and was not intended for use in caustic chemicals. However, because all the exposed surfaces of the probe are made from plastics and polymers that are inert to caustic solutions, it proved to be sufficiently resistant to the chemicals used in this study. Although output readings. expressed in terms of percent of saturation were consistent, and corresponded well to the degree of saturation (as established by tests with aerated and deoxygenated solutions), the alternative output readings in terms of $\mathrm{mg}$ oxygen per liter are significantly higher than the true values in these solutions. This is because the oxygen solubility in water, for which the 
internal calibrations of the instrument are set, is significantly higher than the corresponding value for $1 \mathrm{M} \mathrm{NaOH}$.

The Model 58 meter also contains a temperature sensor, and automatically corrects for temperature effects. These corrections may not be entirely accurate for the solutions used. However, the relative readings are believed to be valid.

Uniform heating of experimental samples was achieved by placing them in a Fisher constant temperature bath with water as a working fluid. Tests with a calibrated thermometer showed that the readout from the thermocouple built into the bath is about 3 to 4 degrees higher than the actual bath temperature. Early experiments, in which a bath temperature of $60^{\circ} \mathrm{C}$ was intended, were found to have only reached $59^{\circ} \mathrm{C}$ when carefully measured with a NIST traceable thermometer, and this temperature was maintained in nearly all subsequent work. The bath proved very stable, maintaining the water temperature within a range of less than $\pm 0.5^{\circ} \mathrm{C}$.

These studies emphasized chemical simplicity and reproducibility. The process solutions of interest contain solid potassium, cesium, and sodium tetraphenyl borates, in addition to dissolved TPB-, sodium hydroxide, sodium nitrate, and sodium nitrite. In these experiments there was no solid tetraphenylborate phase present, the nitrate and nitrite salts were omitted, and only one concentration of sodium hydroxide $(1.0 \mathrm{M})$ was used. These conditions were adopted to ensure both the relative reliability of oxygen meter readings and the complete solubility of tetraphenylborate. The concentration of sodium. hydroxide was chosen as a representative low value for processing.

In general the technique used was to prepare a large volume of stock solution and to fill a number of individual sample vessels with this solution. The vessels were each withdrawn and sampled after a predetermined time. A portion of the stock solution was also analyzed along with the experimental solutions.

Initial experiments conducted in sealed plastic bottles emphasized the need for strict sealing of the experimental vessels against air in leakage. After testing a number of experimental arrangements, the vessel shown schematically in Figure 3 was adopted as a standard. This container can be filled with either aerated or nitrogen-purged solution through a transfer line attached to the dip leg. After filling, the vessel is placed in the constanttemperature bath with the stopcocks open, so that thermal expansion during heating is relieved. Temperature equilibration of the vessel requires about a half hour; diffusion of air into the vessel during this time is minimized by the narrow passage through the stopcock bore. Following equilibration the stopcocks are closed and the vessel is allowed to remain in the bath for the desired time. On removal from the bath, the vessels are strong enough to withstand the compressive forces from cooling. They are cooled in ambient air, and not opened for an hour after cooling. At this point they are close to 
ambient temperature, as shown by measurement of cell temperatures during oxygen analysis.

Air or nitrogen sparging of test solutions was performed in a vessel designed for this purpose. Gases were bubbled into the solution from a fritted tube for at least five minutes. The solution was then transferred into the experimental vessels using the same pressurized gas.

Solutions prepared for these experiments were made with weighed quantities of reagent-grade chemicals and measured volumes of water. The exception . was triphenylborane (3PB), which was added as a measured volume of filtered reagent-grade solution of triphenyborane-sodium hydroxide adduct. The filtered solution contained significant amounts of the other phenyl borates and phenol as impurities. The other phenyl borates contained no measurable impurities of this kind. Prior to loading the experimental solutions into vessels, cupric nitrate solution was placed in the vessel using calibrated micropipets. Generally $0.20 \mathrm{ml}$ of $0.1 \mathrm{M}$ cupric nitrate solution was added to approximately $150 \mathrm{~mL}$ vessels, producing a copper concentration of about $0.00013 \mathrm{M}$. In some experiments a similar amount of $0.025 \mathrm{M}$ cupric nitrate solution was added, so that the copper concentration was about $0.00003 \mathrm{M}$.

Chemical analyses of the test solutions were performed by Analytical Services. The phenyl borates and related compounds (e. g. phenol) were quantified by high pressure liquid chromatography (HPLC). Near the end of these tests analytical chemists discovered that the HPLC method, which was calibrated for the analysis of simulated plant solutions containing up to $5 \mathrm{M}$ sodium ion, gives results that are as much as $15 \%$ low in solutions containing $1 \mathrm{M}$ sodium. This is consistent with a similar observed discrepancy between the amounts of phenyl borates weighed.into these solutions and the analytical measurement of the stock solutions. Results, as reported, continued to be used in evaluating the experiments, since they still permit the desired relative comparisons. Dissolved copper analyses were made using ICP/FS. Benzene was not analyzed because of its volatility. However, benzene was evident in some samples as a small amount of second phase.

Solutions to be analyzed for oxygen content were transferred through plastic lines to the measurement cell shown in Figure 4 by nitrogen pressure. The cell and transfer line were purged with nitrogen before the transfer. Equilibration of the probe with the solution is quite fast, usually requiring a minute or less. Operation of the magnetic stirrer is required for reliable results. Because the joint around the probe was not air-tight, immediate oxygen measurement was desirable. Thus the procedure.was to fill the cell well above the probe level, and record the value as soon as it had equilibrated. 


\section{Quality Assurance}

Quality assurance procedures given in Reference 6 were followed. Specific procedures included at least daily calibration of the oxygen instrument against moist air, and at least weekly measurement of the bath temperature against a traceable thermometer. Stock and experimental samples were analyzed repeatedly to ensure their stability. In some cases multiple samples were taken from the same vessel to ensure uniformity. No differences among duplicates were identified outside the $\pm 5 \%$ range of analytical uncertainty. The known potential sources of variability were concentration of the solutions during air or oxygen purges, and small variations in copper concentration as a result of variations in vessel volume. To avoid sample concentration, purge times were all in the range of five to eight minutes; experiments had shown that this was adequate to equilibrate the samples with the desired atmosphere.

\section{Experimental Results:}

\section{Preliminary Tests}

Initial tests used solutions containing $2 \mathrm{~g} \mathrm{NaTPB}-$ per liter in $1 \mathrm{M} \mathrm{NaOH}$. Copper catalyst was added in one of three ways: as $\mathrm{Cu}\left(\mathrm{NO}_{3}\right)_{2}$ solution, as solid $\mathrm{Cu}_{2} \mathrm{O}$, or as copper beads. Fach of these introduced copper into the solution at concentrations of at least $5 \mathrm{mg} / \mathrm{L}$. No significant decomposition of TPB- was observed. During these initial experiments, oxygen was always present in the solutions, except when cuprous oxide powder was added.

Cuprous oxide was an efficient oxygen scavenger, reacting rapidly with dissolved oxygen to form cupric compounds.

Further experiments used the cells depicted in Figure 3. Indication of decomposition was observed only in two samples that contained cuprous oxide (and therefore had no dissolved oxygen during heating). These samples were heated for more than two hundred hours.

Additional tests used aerated solutions of $10 \mathrm{~g} \mathrm{NaTPB}$ per liter in $1 \mathrm{M} \mathrm{NaOH}$. Evidence for decomposition of TPB- was seen in only one sample, in which 0.25 gram of a simulated sludge powder was added to the solution in a plastic bottle and the bottle heated for two days. (This solution may also have contained a small amount of cupric nitrate solution.) The simulated sludge powder coated the bottom and sides of the plastic bottle. More than 10\% decomposition of TPB- was observed. It had been found in the preliminary work that the plastic bottle used in this test was not air-tight, and as expected this solution contained a substantial amount of dissolved oxygen.

Although these preliminary tests showed no evidence of TPB- decomposition in the presence of copper alone, there was evidence in the longest heated samples that oxygen was consumed by reaction. Similar experiments by 
Barnes showed a very slow evolution of benzene, consistent with this observation: 2

These preliminary experiments showed consistent behavior. The stock solutions of $\mathrm{NaTPB}$ were not entirely clear, but exhibited a slight opalescence. When the cupric nitrate solution contacted the alkaline solution, a bright blue gelatinous hydroxide formed, which gradually turned into a black cupric oxide precipitate after an hour or two in the heated bath. The opalescent material also precipitated on heating as agglomerates of white crystals in the bottom of the vessel. Analysis of these solids showed no organic content, indicating that the white material is an inorganic impurity such as silicate. The heated solution became quite clear. In later studies, where decomposition of TPB- was observed, this clear solution immediately began to become cloudy on cooling, suggesting precipitation of dissolved benzene or other organic material.

\section{Systematic Experiments}

\section{Tetraphenylborate hydrolysis in the presence of copper}

These experiments were done to test the TPB- hydrolysis rate against oxygen concentrations. On the premise that the material reacting with oxygen, whether TPB- or an impurity, would react in proportion to its concentration (while the oxygen concentration remained fixed), a series of tests was run at higher concentrations of TPB', $25 \mathrm{~g} / \mathrm{L}$. In each sample the solution $(25 \mathrm{~g} / \mathrm{L}$ NaTPB in $1 \mathrm{M} \mathrm{NaOH}$ ) was sparged with air for at least five minutes before being added to the sealed vessel. Cupric nitrate solution $(0.20 \mathrm{~mL}$ of $0.1 \mathrm{M}$. Cu) was added to the vessel prior to the test solution. After a period of time in the heated bath, the vessel was withdrawn, cooled, and analyzed for . oxygen, TPB-, and its decomposition products. Results are tabulated in Table 1 and shown schematically in Figure 5. As shown in the table, the oxygen saturation decreased steadily as a function of time, until it was completely depleted at the longest time tested. Only at this time were decomposition products of TPB- observed.

On the premise that the oxygen was inhibiting hydrolysis of TPB-, a sample of the same solution was purged with nitrogen to remove air, transferred to a nitrogen-purged vessel, sealed, and heated. As indicated in Table 1 and Figure 5, this sample showed significant TPB- decomposition, confirming the premise that oxygen inhibits the catalytic hydrolysis of the TPB- ion.

The observation that smaller concentrations of TPB- consumed the oxygen - present more slowly indicates that the reaction removing oxygen is proportional to the concentration of either TPB- or of an impurity associated with the TPB-. This reaction evidently does not produce a measurable amount of phenyl borates or phenol, but as the dissolved oxygen present is only a few $\mathrm{mg} / \mathrm{L}$, this is not surprising. 


\section{Phenylboronic acid (1PB) hydrolysis}

Because questions had arisen about the copper-catalyzed reactions of 1PB, experiments similar to those performed with TPB- were performed with phenylboronic acid. A measured amount of $1 P B$ (usually $2 \mathrm{~g} /$ ) was added to a solution of $1 \mathrm{M} \mathrm{NaOH}$, and the resulting solution placed into a vessel containing cupric nitrate, as in the TPB- experiments described in the preceding section. The effect of oxygen was evaluated by air purging or nitrogen purging the solutions before adding them to the experimental vessels. The concentration of cupric ion was also varied. Results are shown in Table 2. The oxygen present was rapidly and completely consumed in all cases. Even after as little as 6.4 hours, little oxygen remained. From 25 to 50 percent of the 1PB was consumed, with production of phenol. The amount of reaction was a function of the initial concentration of IPB as well as the copper concentration. The data suggest that, after a rapid initial reaction, any further reaction was very slow or nonexistent. The two tests at the bottom of the table show the decreased reaction at lower copper content. (The apparent non-reaction shown by difference is probably the result of a low analysis of the 1PB content of the stock solution. The sample preparation procedure should have produced a 14 to $15 \mathrm{mM}$ solution. )

To test the hypothesis that the consumption of oxygen and the extent of reaction are related, an experiment was conducted as shown schematically in Figure 6. A solution containing $135 \mathrm{~mL}$ of $2 \mathrm{~g} / \mathrm{L} \mathrm{IPB}$ in $1 \mathrm{M} \mathrm{NaOH}$ was placed in a vessel containing approximately $0.00013 \mathrm{M}$ cupric nitrate solution. This vessel was connected by tubing to a second vessel containing $1 \mathrm{M} \mathrm{NaOH}$. Both vessels were fitted with a fritted disk in the bottom of the vessel so that air could be bubbled through the train continuously. The air stream passed first through the vessel containing only $1 \mathrm{M} \mathrm{NaOH}$ to hydrate it, and thereby minimize the loss of liquid by evaporation from the 1PB solution. As shown in Figure 7 and Table 3, the 1PB concentration in the second vessel decreased rapidly over a period of a few hours. Substantial amounts of phenol were produced, corresponding nearly quantitatively to 1PB losses. This experiment confirms that, in the presence of air, the decomposition of IPB continues, with a rate varying with $1 \mathrm{~PB}$ concentration. Phenol is the principal product. It is attractive to attribute the hydrolysis of 1PB to catalysis by cupric ion, which undergoes reduction in the absence of oxygen. These 1PB samples when recovered showed no black cupric oxide (CuO), in contrast to aerated TPB- solutions, in which $\mathrm{Cu}_{2} \mathrm{O}$ was visible as long as the solution remained oxygenated.

\section{Mixed TPB- and 1PB Experiments}

Because TPB- hydrolyzes in the absence of air, and IPB reacts to remove air from solution, experiments were performed with the two compounds in combination in the same solution. The hypothesis was that 1PB might accelerate the overall reaction through removing air. This was confirmed in these experiments. 
A solution of $10 \mathrm{~g} / \mathrm{L}$ NaTPB- and $2 \mathrm{~g} / \mathrm{L} 1 \mathrm{~PB}$ was prepared in $1 \mathrm{M} \mathrm{NaOH}$. Vessels containing $0.20 \mathrm{~mL}$ of $0.1 \mathrm{M}$ cupric nitrate solution (approximately $0.00013 \mathrm{M}$ copper) were filled with the aerated TPB-/1PB solution and placed in the heated $\left(59^{\circ} \mathrm{C}\right)$ bath. Vessels were withdrawn and analyzed periodically. As expected, oxygen was absent (or nearly so) in all vessels analyzed. Compositional data are given in Table 4. The 1PB and TPBconcentrations as a function of time are shown in the graph in Figure 8. The TPB- began to decompose soon after being placed in the bath, and continued to be destroyed through the experiment. The 1PB at first behaves much as it did in the absence of TPB-, decreasing rapidly to a fraction of its original concentration. At the longest times its concentration increased, presumably by ingrowth of 1BP formed from decomposed TPB-.

Copper analysis of these solutions showed that most.or all of the copper added was present in solution. If it is accepted that cupric ion $\left(\mathrm{Cu}^{2+}\right)$ catalyzes 1PB decomposition, and that cuprous ion $\left(\mathrm{Cu}^{+}\right)$catalyzed the decomposition of 'TPB', then copper was probably in the cuprous state during most of this experiment.

\section{Triphenylborane experiments}

Because the copper-catalyzed decomposition of TPB- and IPB showed quite different behavior toward oxygen, the other phenyl borates were also studied, beginning with experiments on triphenylborane (3PB).

Three vessels were prepared containing filtered triphenylborane solution in $1 \mathrm{M} \mathrm{NaOH}$. The solutions were aerated and placed in sealed vessels in the bath. There was insufficient stock solution to fill three vessels, so a head space containing air and amounting to about 20\% of the vessel-volume remained in the third vessel. All samples contained approximately 0.00013 M cupric nitrate solution. (The copper concentration would therefore have been about 25\% higher in the vessel containing an air space.)

Results are shown in Table 5. The two samples that contained no gas phase became anoxic in less than two days, and the 3PB had substantially reacted during that time. The sample containing the air space proved interesting. This solution never became anoxic, and the 3PB reacted much less than in the other two samples. However, in this aerated system, the diphenyl and monophenyl products were completely consumed and produced phenol. It appears that triphenylborane hydrolyzes whether or not air is present, but does so more rapidly in the absence of air. This suggests that cuprous ion is a more effective catalyst than cupric ion for this reaction.

V. Diphenylborinic acid experiments.

A brief series of experiments investigated the copper-catalyzed reaction of diphenylborinic acid in $1 \mathrm{M} \mathrm{NaOH}$. In all these tests the solutions were 
initially oxygen saturated. One test repeated the arrangement used in the triphenylboron experiments, in which a $20 \%$ head space filled with air was left in the vessel. The effect of varying the copper concentration was also investigated.

The three vessels that contained only solution were found to have become anoxic when analyzed. The vessel containing an air space was not anoxic, but its oxygen content was substantially reduced. The results (Table 6) clearly show that decomposition of diphenylborinic acid occurs with or without air present, but is much faster in the presence of air. They also show the strong effect of copper concentration on the rate.

VI. Catalysis by sludge.

As a result of the scouting experiments, and in accordance with the technical plan, three experiments on TPB- decomposition were run with a synthetic -sludge powder added as a catalyst instead of copper. In each case, $0.25 \mathrm{~g}$ of dried synthetic sludge powder, obtained from $D$. D. Walker, was added to the vessel before it was filled with oxygenated $10 \mathrm{~g} / \mathrm{L}$ NaTPB- solution in $1 \mathrm{M}$ $\mathrm{NaOH}$. Note that the sludge was poorly wetted when added this way, and tended to clump up in the bottom of the vessel. Thus a minimum surface area was available for any heterogeneous catalysis. The three vessels were heated for 48,92 , and 150 hours, respectively, then analyzed. No measurable decomposition products of tetraphenylborate were seen in any of these samples. .

\section{Conclusions}

A plausible explanation of the observed results involves catalysis of the decomposition reactions by both cuprous and cupric ions. Cuprous ion is formed by reaction of cupric ion with organic material, but can persist only in oxygen-free solution. The relative effectiveness of the two ions for catalysis can therefore be determined from the reaction rates in the presence and absence of oxygen.

In this model, TPB- would show very little catalysis by cupric ion, $\mathrm{Cu}^{2+}$, with only a very slow reaction 80 long as oxygen is present to stabilize $\mathrm{Cu}^{2+}$. Triphenylboron reacts more rapidly with $\mathrm{Cu}^{2+}$ (Table 5), but much less rapidly than does the diphenylborinic acid (Table 6). 1PB reacts very quickly in the presence of cupric ion, with most of the reaction being completed in a few hours (Figure 7).

The behavior toward cuprous ion is the converse. TPB- decomposes in the presence of cuprous ion, although the absolute rate of this reaction is slow compared to corresponding reactions of the other phenyl borates. Triphenylboron hydrolyzes faster in the presence of cuprous ion than with cupric ion. Diphenylborinic acid also reacts significantly faster in the 
presence of $\mathrm{Cu}(\mathrm{I})$ than does TPB- (Table 6), but 1PB reacts only slowly, if at all, once copper is reduced to this valence (Table 2).

Oxygen is consumed in these reactions in substantial part in the generation of phenol. For 1PB, conversion of the hydrolyzed material to phenol is nearly quantitative, as indicated by comparing the curves in Figure 7. Variations in the amount of phenol produced in apparently similar samples may correspond to variations in experimental technique, such as variations in the length of time the vessel vents were open during temperature equilibration.

\section{References}

1. D. D. Walker, M. J. Barnes, C. L. Crawford, R. F. Swingle, R. A. Peterson,

M. S. Hay, and S. D. Fink, "Decomposition of Tetraphenylborate in Tank 48H (U)", WSRC-TR-96-0113, Rev. 0, May 10, 1996.

\footnotetext{
2. M. J. Barnes and T. B. Edwards, "Copper Catalyzed Sodium
Retraphenylborate Decomposition Kinetic Studies (U)", WSRC-TR-96-0351,
Rev. November 7, 1996.

3. D. T. Hobbs, "Concentrations of Metals and Non-Metals in Alkaline Waste

1. Slurries (U)", WSRC-TR-96-0058, April 3, 1996.
}

it "4 "4. J. E. Marra, "Technical Task Request, $\mathrm{O}_{2}$ Induction Period Testing", HLEof TIR-97011, November 14, 1996.

1. 5. M. L. Hyder, "Task Technical Plan for Studies of Oxygen Consumption in the Catalyzed Hydrolysis of Tetraphenylborate Ion (U)", WSRC-RP-96-0612, Rev. 0, December 9, 1996.

2. 6. M. L. Hyder, "Task Quality Assurance Plan for Studies of Oxygen Consumption in the Catalyzed Hydrolysis of Tetraphenylborate Ion (U)", WSRC-RP-96-0777, Rev. 0, December 31, 1996. 


\section{Table 1}

Copper-Catalyzed Hydrolysis of Sodium Tetraphenylborate (NaTPB) Solution

Conditions: $1 \mathrm{M} \mathrm{NaOH}, \mathrm{Cu}^{++}$approximately $0.00013 \mathrm{M}, 59^{\circ} \mathrm{C}$.

Time at

Analyses

Temp.,

hours

Aerated Samples:

0 N/A 0.0

$115.7 \quad 1.8$

$141.0 \quad 2.0$

$213.5 \quad 1.0$

$280.7 \quad 0.6$

377.1

0.0

Nitrogen Purged Sample:

114.9

0.0

$0.054 \quad 4.6$

2PB $\mathrm{mM}$ $\mathrm{mM}$

0.066

0.065

0.070

0.068

0.067

0.063

$<0.04$

$<0.04<0.06$

$<0.04<0.08$

$<0.04$

$<0.06$

$<0.04$

$<0.08$

1.3

4.0

3.5

$<0.2$

$<0.2$

$<0.2$

ND

$<0.2$

$-2.0$

1.1

$<0.1<0.06$

$<0.1<0.06$

$<0.2 \quad 0.05$

ND $\quad<0.06$

$<0.2 \quad 0.09$

$1.1<0.06$

Abbreviations: TPB-: tetraphenylborate ion; 3PB: triphenylborane; 2PB:

diphenylborinic acid; 1PB: phenylboronic acid; P-P: biphenyl; ND: not determined. 


\section{Table 2}

Copper-Catalyzed Hydrolysis of Phenylboronic Acid (1P.B)

Conditions: $1 \mathrm{M} \mathrm{NaOH}, 59^{\circ} \mathrm{C}$.

\begin{tabular}{|c|c|c|c|c|}
\hline Time at & $\underset{\mathrm{mM}}{\text { Initial }}$ 1PB & $\underset{\mathrm{mM}}{\text { Final IPB }}$ & $\begin{array}{r}\text { Phenol } \\
\mathrm{mM}\end{array}$ & 1PB Destroyed \\
\hline Aerated & Samples: $\mathrm{Cu}$ & 3) approxi & Ly 0.0001 & \\
\hline 6.4 & 3.4 & 2.3 & 0.49 & 31 \\
\hline 21.7 & 3.4 & 2.1 & 0.39 & 37 \\
\hline 24.1 & 3.4 & 1.6 & 0.36 & 54 \\
\hline 16.2 & 15 & 8.3 & 4.1 & 44 \\
\hline 40.6 & 15 & 8.6 & 3.4 & 42 \\
\hline 47.6 & 15 & 8.7 & 3.3 & 41 \\
\hline 65.6 & 13 & 9.6 & 0.56 & 25 \\
\hline 89.3 & 15 & 8.8 & 0.54 & 40 \\
\hline 92.2 & 14 & 7.0 & 4.1 & 49 \\
\hline 137.5 & 15 & 7.0 & 1.4 & 52 \\
\hline
\end{tabular}

Nitrogen Purged Samples: $\mathrm{Cu}\left(\mathrm{NO}_{3}\right)_{2}$ approximately $0.00013 \mathrm{M}$

$\begin{array}{llllll}23.9 & 3.4 & 1.8 & 0.26 & 41 \\ 22.7 & 13 & 9.6 & 1.7 & 25 \\ 23.6 & 14 & 8.3 & 2.0 & 39\end{array}$

Aerated Samples: $\mathrm{Cu}\left(\mathrm{NO}_{3}\right)_{2}$ approximately $0.00003 \mathrm{M}$

$\begin{array}{lllll}22.7 & 13 & 13 & 1.4 & (0) \\ 46.8 & 13 \ldots & 13 & 1.2 & (0)\end{array}$

\section{Table 3}

Phenylboronic Acid (1PB) Destruction in Continuously Aerated Solution

Conditions: $60^{\circ} \mathrm{C}$, continuously purged with moist air, $1 \mathrm{M} \mathrm{NaOH}$ solution initially containing $0.136 \mathrm{M} 1 \mathrm{~PB}$ and $0.00015 \mathrm{M} \mathrm{Cu}^{++}$

\begin{tabular}{lrcc} 
Time, hr & 1PB.M & Phenol, M & \% 1PB destroyed \\
\hline 2.1 & 5.4 & 7.6 & 60 \\
3.7 & 3.4 & 9.6 & 75 \\
6.5 & 1.8 & 11.1 & .87
\end{tabular}


M. L. Hyder.

\section{Table 4}

\section{Reaction of Mixed 1PB/NaTPB Solutions}

Conditions: $1 \mathrm{M} \mathrm{NaOH}$, Approximately $0.00013 \mathrm{M} \mathrm{Cu}^{++}, 59^{\circ} \mathrm{C}$; all samples initially aerated.

\begin{tabular}{|c|c|c|c|c|c|}
\hline \multirow{2}{*}{$\begin{array}{l}\text { Time at } \\
\text { Temperature }\end{array}$} & \multicolumn{4}{|c|}{ Analyses } & \multirow[b]{2}{*}{$\begin{array}{c}\text { Phenol } \\
\text { mM }\end{array}$} \\
\hline & $\begin{array}{l}\text { TPB } \\
M\end{array}$ & $\begin{array}{l}3 \mathrm{~PB} \\
\mathrm{mM}\end{array}$ & $\begin{array}{l}2 \mathrm{~PB} \\
\mathrm{mM}\end{array}$ & $\begin{array}{l}\text { IPB } \\
\mathrm{mM}\end{array}$ & \\
\hline 0 & 0.024 & 0.0 & 0.0 & 12.6 & $<0.1$ \\
\hline 23.7 & 0.024 & 0.68 & 0.24 & 5.6 & 4.8 \\
\hline 46.5 & 0.024 & 0.65 & 0.14 & 5.6 & 4.9 \\
\hline 70.9 & 0.023 & 1.19 & 0.50 & 6.7 & 3.8 \\
\hline 139.0 & 0.021 & 1.32 & 0.75 & 6.6 & 4.1 \\
\hline 215.7 & 0.020 & 1.35 & 0.52 & 3.2 & 1.6 \\
\hline 310.9 & 0.017 & 1.14 & 1.39 & 11.6 & 0.7 \\
\hline 453.7 & 0.012 & 0.78 & 0.72 & .11 .5 & 3.3 \\
\hline
\end{tabular}

Abbreviations: 3PB: triphenylborane; 2PB: diphenylborinic acid; 1PB: phenylboronic acid; P-P: biphenyl. 


\section{Table 5 Copper-Catalyzed Reactions of Triphenylborane}

Conditions: $1 \mathrm{M} \mathrm{NaOH}$, Approximately $0.00013 \mathrm{M} \mathrm{Cu}^{++}, 59^{\circ} \mathrm{C}$; all samples initially aerated.

Time at

Temp,hr<smiles>[TeH]</smiles>

43.0

139.4
Analyses, $\mathrm{mM}$

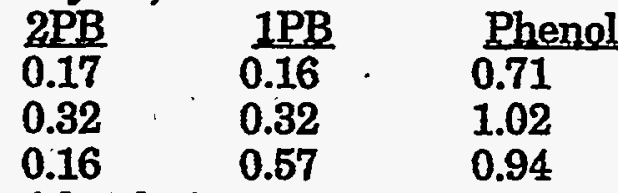

Sample with air in contact with solution: 45.3 1.41 $<0.06<0.12$

1.96

\section{Table 6}

\section{Copper-Catalyzed Reactions of Diphenylborinic Acid}

Conditions: $1 \mathrm{M} \mathrm{NaOH}, 59^{\circ} \mathrm{C}$; all samples initially aerated.

Time at Analyses, $m M$

Temp.hr 1PB Phenol

Copper added =approximately $0.00013 \mathrm{MCu}^{++}$ 0 22.8 4.5

95.3 1.3

19

0.82

Copper added $=$ Approximately $0.00003 \mathrm{MCu}^{++}$ 22.8 3.6 0.83 0.48

Sample with air in contact with solution (Approximately $0.00013 \mathrm{MC} \mathrm{Cu++)}$. 22.8 $<0.06$ 


\section{YSI MODEL 58 DISSOLVED OXYGEN METER}

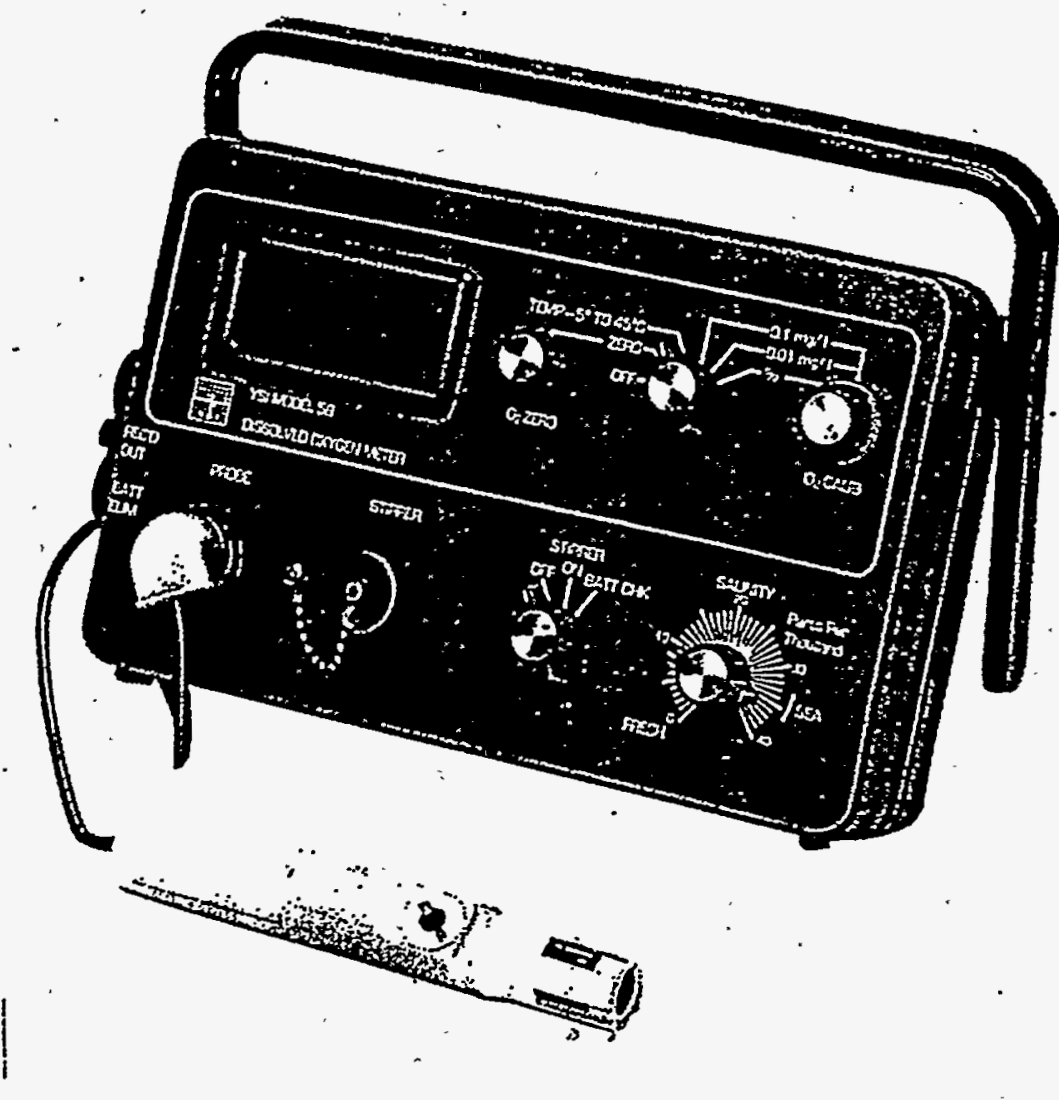

Figure 1: Oxygen Meter With Probe 


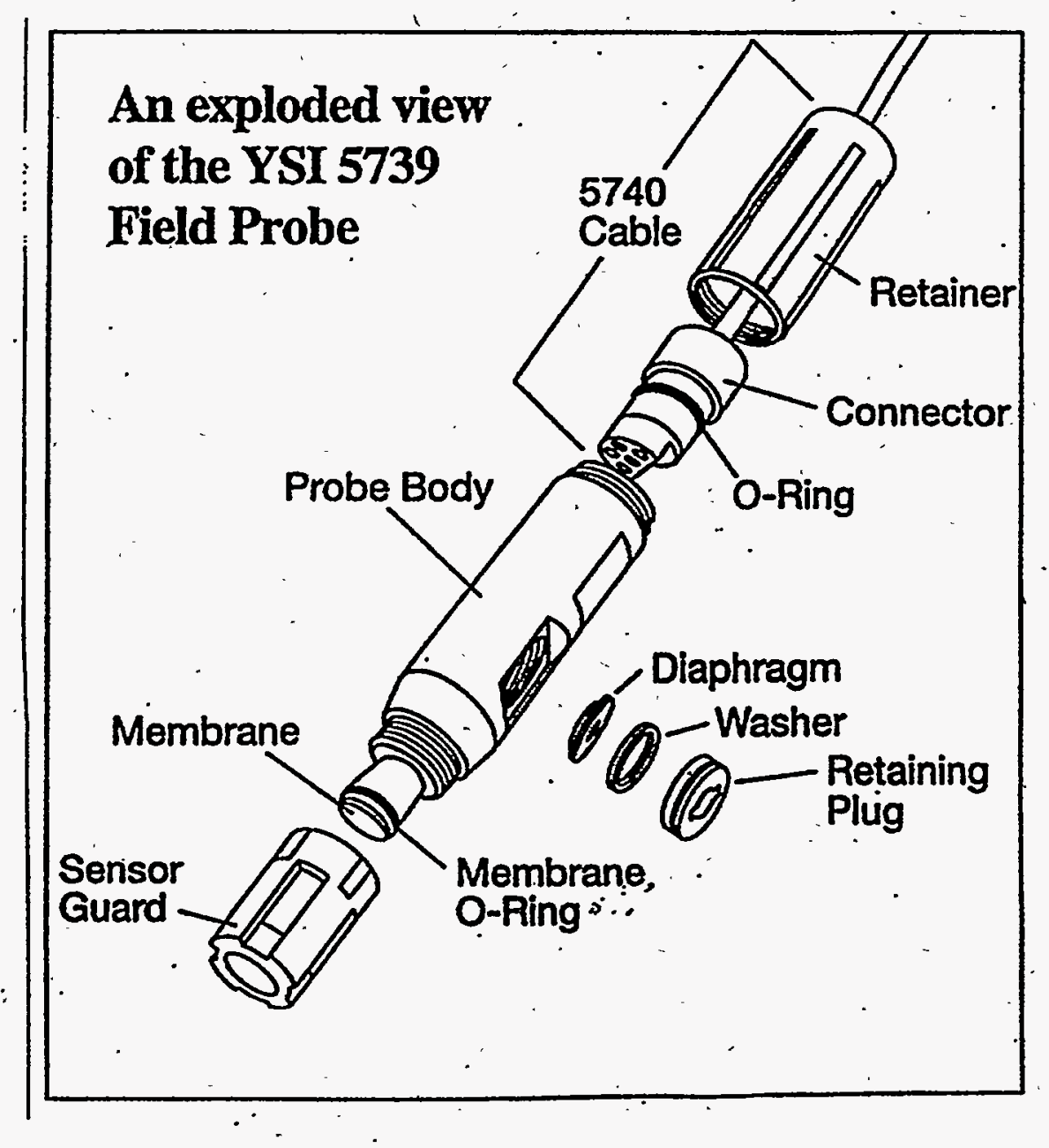

Figure 2: Oxygen Probe 
M. L. Hyde WSRC-TR-97-0069, Rev. 0

Page 17 of 22

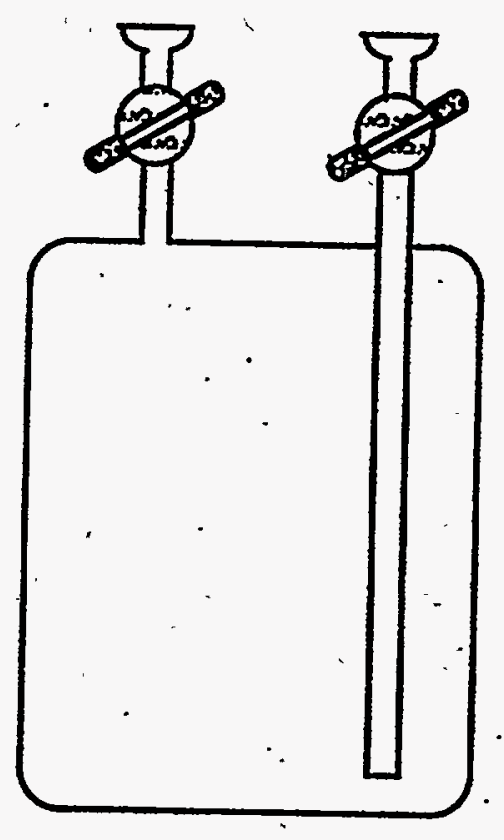

Figure 3: Schematic Drawing of a Sample Cell 


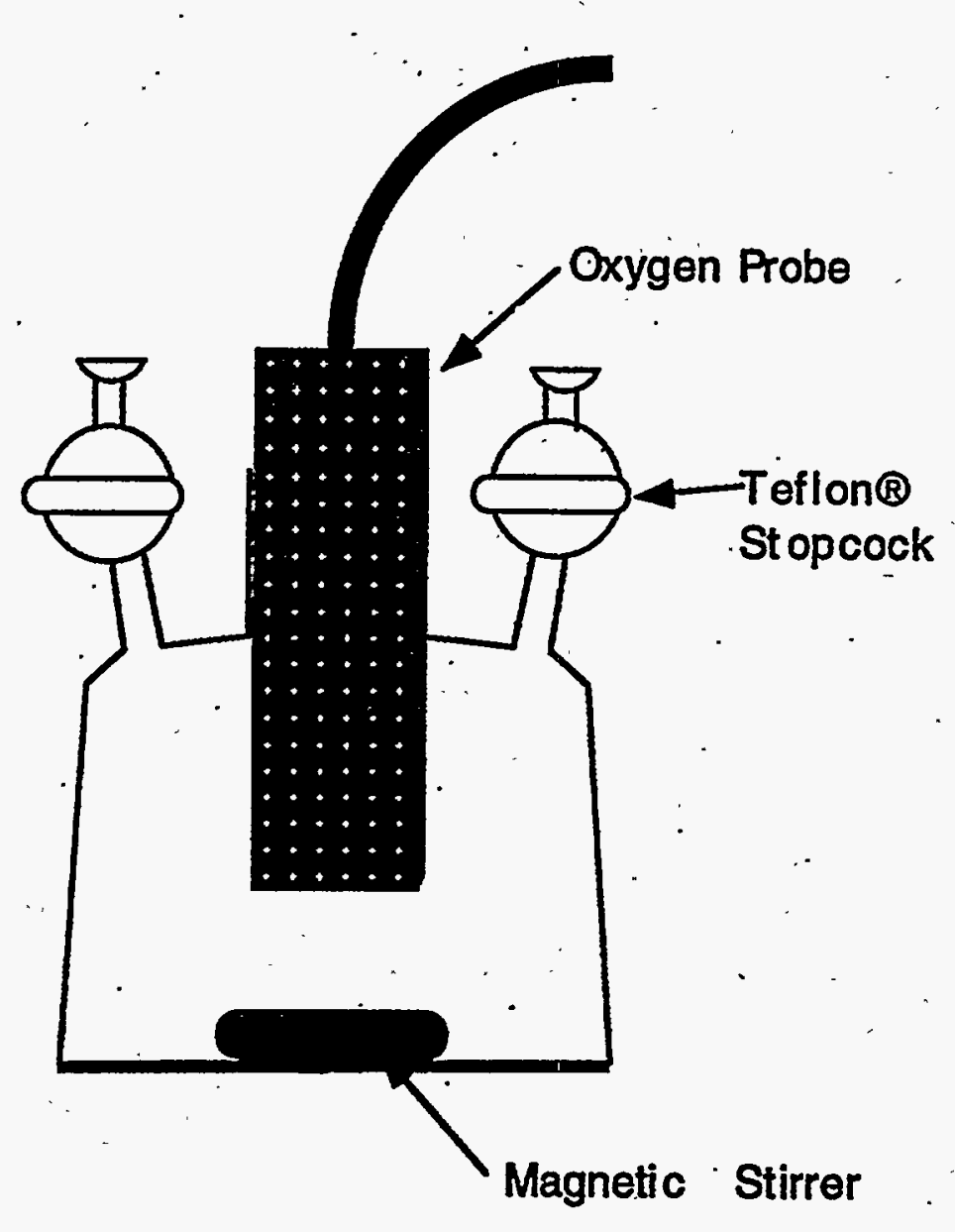

Figure 4: Measurement Cell (Pyrex Glass) : 


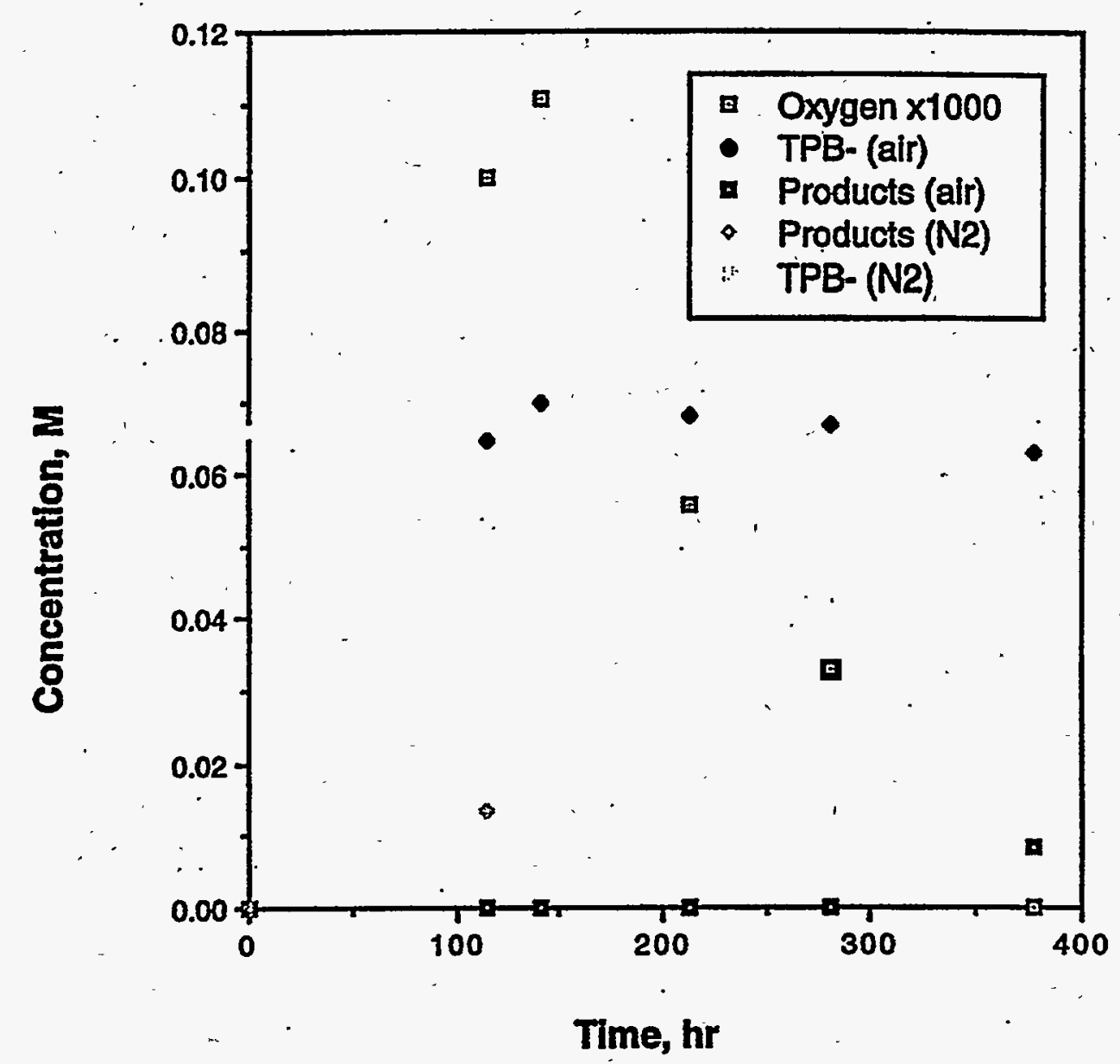

Figure 5: Cu-Catalyzed Decomposition of TPB- 


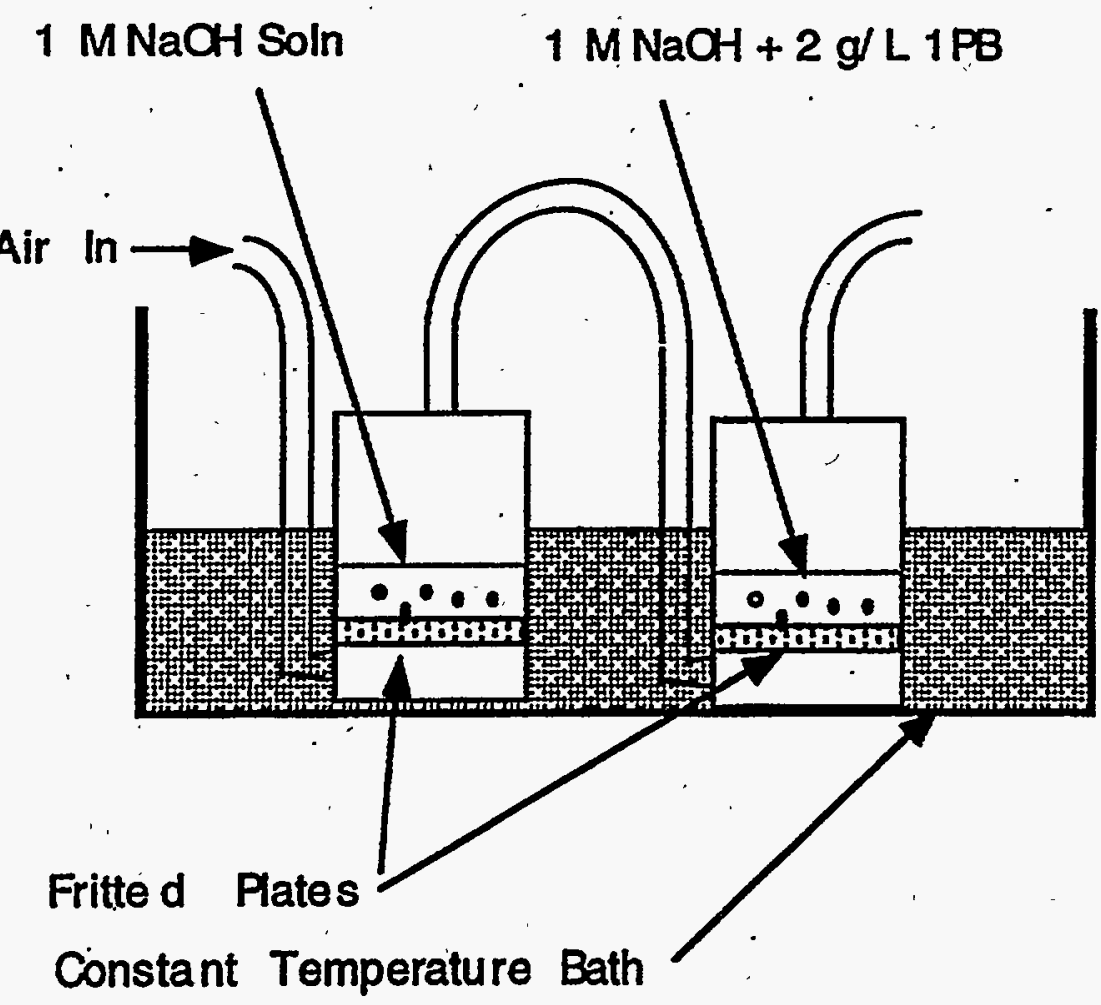

Figure 6: 1FB Aeration Experiment 


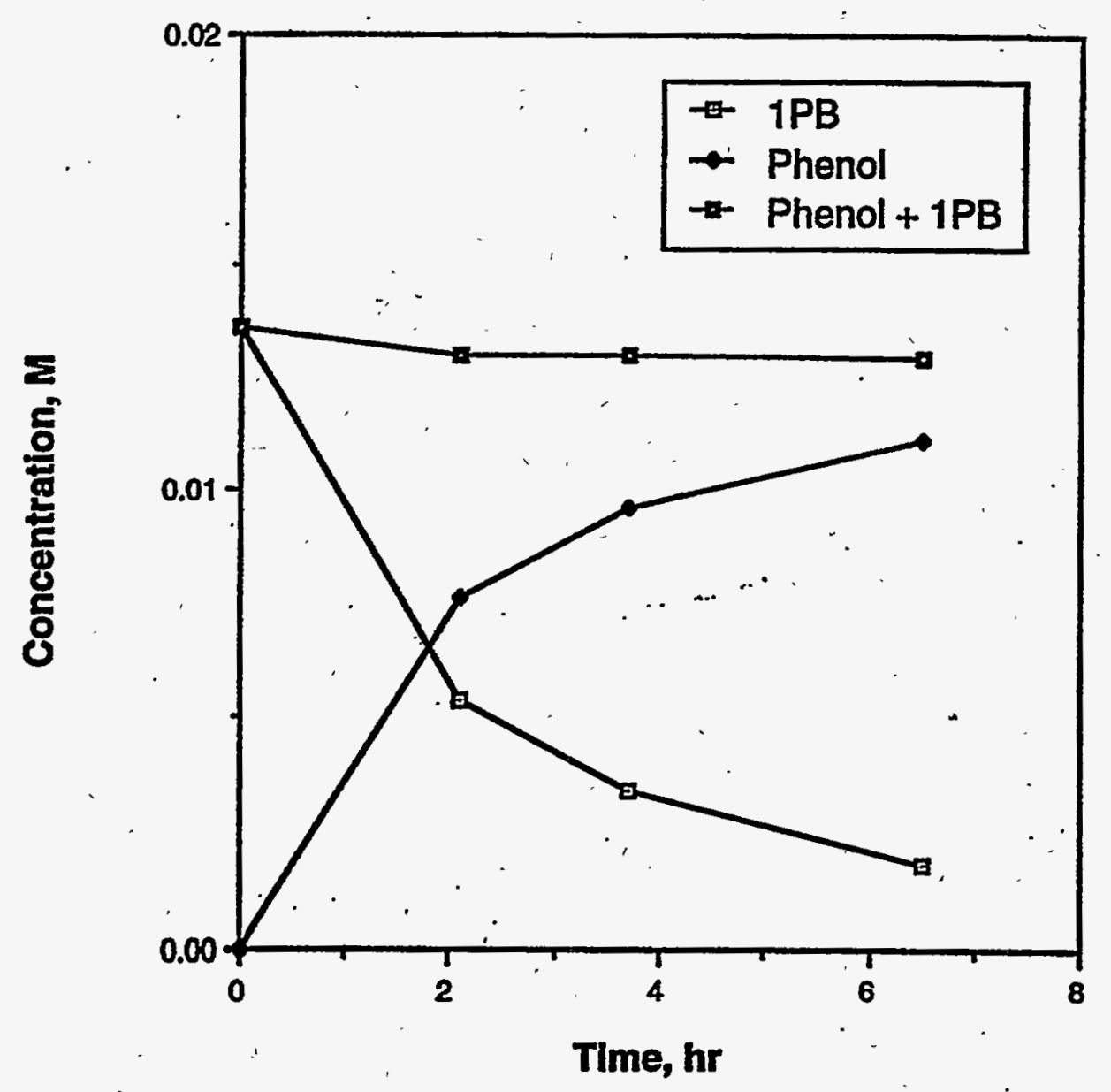

Figure 7: Continuously Aerated IPB 


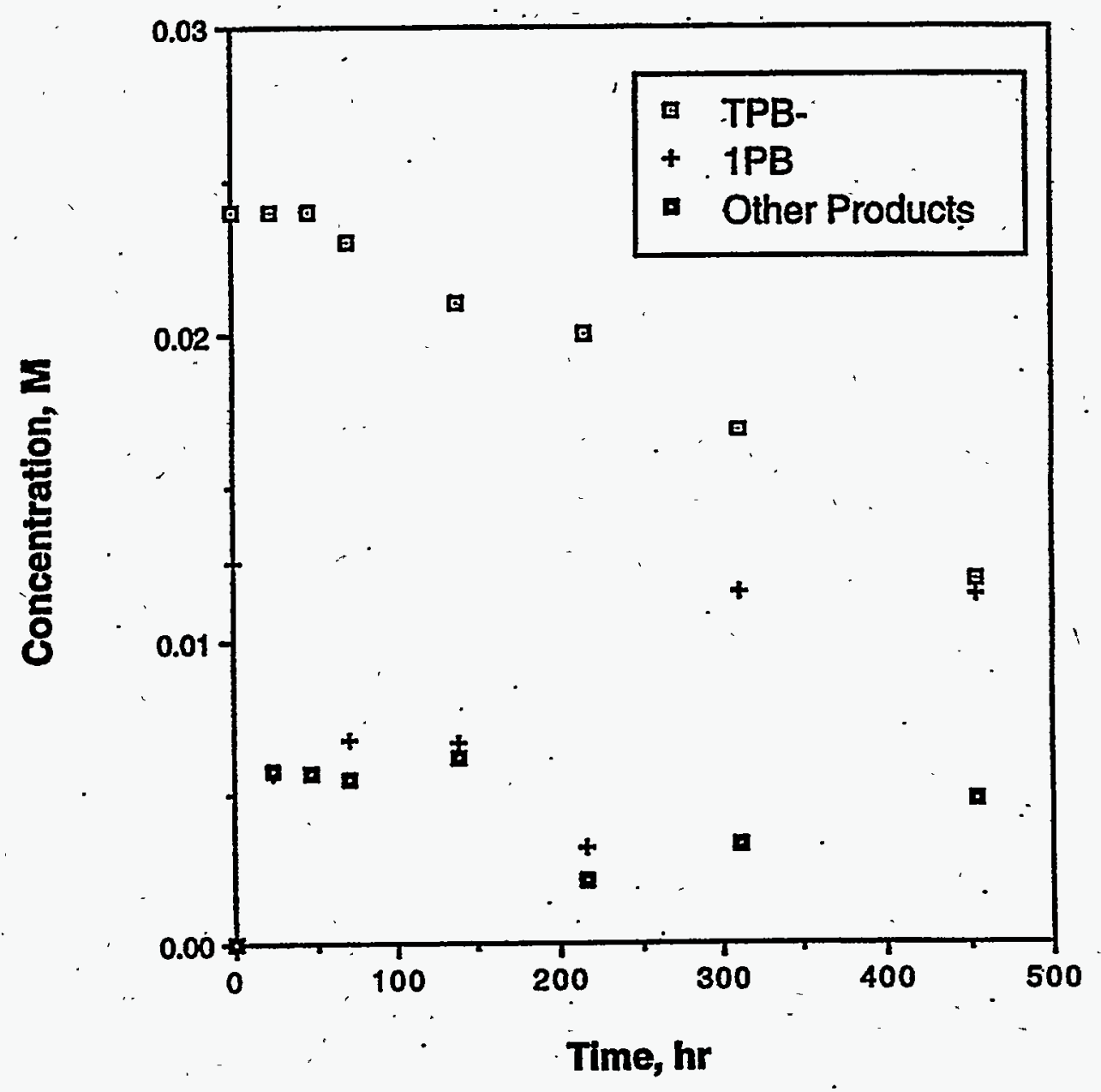

Figure 8: Mixed TPB- and 1PB Solution 
Amerine, D. B., 719-4A

Barnes, M. J., 773-A

Britt, T. E., 730-2B

Byrd, D., 704-56H

Carter, J. T., 704-25S

Cauthen, G. L., 241-119H

Clark, W. C., 241-119H

Crawford, C. L., 773-43A

Eberlein, S. J., 704-56H

Eibling, R., 704-T

Elder, H. H., 704-S

Fink, S. D., 773-A

Fowler, J. R., 241-121H

Griffin, J. C., 773-A

Hitchler, M. J., 730-2B

Holtzscheiter, E. W., 773-A

Hyder, M. L, 773-A

Jacobs, R. A., 704-T

Johnson, M. D., 704-56H.

Keefer, M. T., 704-56H

Landon, L. F., 704-T

Lewis, B. L., 703-H

Lex, T. J., 719-4A

Marek, J. C., 704-T
McCabe, D. J., 773-43A

Menna, J. D., 241-119H

Miller, M. S., 704-56H

Montini, M. J., 704-56H

Morin, J. P., 719-4A

Nash, C. A., 773-A .

Nelson, L. M., 773-43A

Papouchado, L. M., 773-A

Peterson, R. A., 773-A

Rutland, P, L., 241-152H

Satterfield, R. M., 719-4A

Swingle, R. F., 773-A

Tamosaitis, W. L., 773-A

Taylor, G. A., 703-H

Van Pelt, W. B., 676-1T

Walker, D. D. 773-A

Wiggins, A. W., 241-152

Wilmarth, W. R., 773-A

Wooten, A. L., 732-B

Wright, G. T., 773-A

TIM, 703-43A

HLWE File Room,File Code 1.2.5.1, 703-H

LWP Files, clo A. Patterson, 773-A

ITP Files, c/o A. G. Wiest, 241-119H 